\title{
Intertemporális tőkeallokációs döntések tartósan alacsony kamatkörnyezetben'
}

\author{
Schepp Zoltán - Ulbert József - Tóth-Pajor Ákos \\ Pécsi Tudományegyetem
}

\begin{abstract}
A TANULMÁNY CÉLJA
A tanulmányban a tartósan alacsony nemzetközi és hazai kamatkörnyezet befektetési és beruházási döntésekre gyakorolt hatásával foglalkoztunk. Arra a kutatási kérdésre kerestük a választ, hogy milyen döntési szabállyal ragadhatjuk meg a döntéshozók intertemporális preferenciáit az alacsony kamatkörnyezetben, ha a tradicionális jelenérték szabály összefüggései nem érvényesülnek.
\end{abstract}

\begin{abstract}
ALKALMAZOTT MÓDSZERTAN
A kutatási kérdés megválaszolása során áttekintettük a releváns szakirodalmat, majd numerikus példák segítségével mutattuk meg a döntéshozók racionálisan elvárható reakcióit, valamint szembeállítottuk a tradicionális jelenérték szabályt alkalmazó döntéshozók és a rövid távú érdekeket elötérbe helyező döntéshozók intertemporális választásait. A döntéshozók szemszögéből, elsősorban módszertani szempontól vizsgálódtunk, és a döntések intertemporális jellegére fókuszáltunk feltételezve, hogy a döntéshozók reakcióit a jelenérték szabály motiválja. A kutatás középpontjában a válságot követő évtized áll, amely egy jól elkülöníthető időszaknak tekinthető az alacsony kamatkörnyezetben bekövetkezett változások bemutatásához.
\end{abstract}

\section{LEGFONTOSABB EREDMÉNYEK, ÚJDONSÁGOK}

A tradicionális jelenérték szabályt alkalmazva megmutattuk, hogy a diszkontráta csökkenése kiszélesíti a befektetési időhorizontot, valamint a jelenérték növekvő volatilitása spekulációnak, hozamvadászatnak ad teret. A tanulmány legfontosabb eredménye annak bemutatása, hogy azokban az esetekben, amikor az intertemporális döntések vonatkozásában nem érvényesül a tradicionális jelenérték szabály, a döntések modellezésére kvázi-hiperbolikus diszkontfüggvényeket alkalmazhatunk, amelyek magyarázatul szolgálnak a beruházások visszaesésére, valamint a tőketranszferek előtérbe kerülésére. A rövid távú érdekeket előtérbe helyező döntéshozók esetében az intertemporális preferenciákat leíró diszkonttöbblet a tradicionális jelenérték szabály által meghatározott értéknél alacsonyabb értéket eredményez, ami értékes befektetési és beruházási lehetőség elutasításához vezethet, ezzel értéket rombol.

\section{GYAKORLATI JAVASLATOK}

A kutatási kérdésünkre válaszként levonhatjuk a következtetést, hogy a hiperbolikus diszkontálás és a kvázi-hiperbolikus diszkontfüggvények alkalmazása az intertemporális tőkeallokációs döntések alternatív döntési keretrendszereként jelennek meg a tradicionális jelenérték szabállyal szemben a monetáris intézkedések hatására kialakult alacsony kamatkörnyezetben.

Kulcsszavak: intertemporális tőkeallokáció, intertemporális preferenciák, alacsony kamatkörnyezet, hiperbolikus diszkontálás, befektetői rövid távú érdekek

DOI: https://doi.org/10.15170/MM.2019.53.02.02

\footnotetext{
${ }^{1}$ A kutatást az Emberi Erőforrások Minisztériumának Felsőoktatási Intézményi Kiválósági Programja finanszírozta, a Pécsi Tudományegyetem 4. tématerületi „A hazai vállalatok szerepének növelése a nemzet újraiparosításában” programja keretében (szerződés száma: 20765-3/2018/FEKUTSTRAT).
} 


\section{BEVEZETÉS}

A válságot követő évtizedben meglehetősen szokatlan világjelenséggel szembesültek a döntéshozók a reálgazdaságban és a tőkepiacokon. Tartósan alacsony kamatkörnyezetben kellett meghozni döntéseiket. A válságot követően kialakuló alacsony kamatkörnyezet alapjaiban befolyásolta a beruházási és a megtakarítási döntéseket. Az intertemporális döntéseket tekintve az ár- érték dilemmák megváltozására ráadásul a racionálisan „elvárható" reakciótól eltérően reagáltak a tőkepiaci és a reálgazdasági szereplök.

A válságra a monetáris politika kamatcsökkentéssel és eszközvásárlási programokkal válaszolt, míg a kormányzati döntéseket Európában a fiskális politikai szigor jellemezte. A monetáris politika célja a gazdaság élénkítése volt, de az intézkedéseket követően meghozott intertemporális döntések nem jellemezhetők a tradicionális jelenérték szabály összefüggéseivel. Az alacsony és nem túl változékony kamatkörnyezetben a pénz idóértéke közel nulla, így a hosszú távon realizálható pénzáramok jelenértéke növekedett, ami a hosszú távú beruházások és tőkebefektetések megvalósításának kedvez. Az intézkedéseknek köszönhetően a tőkepiacok felélénkültek, korábban soha nem látott mértékủ hozamvadászat vette kezdetét. Az alacsony kamatkörnyezetben a jelenérték növekvö volatilitása spekulációnak adott teret. A tőkepiacokon a befektetők rövid távú érdekeinek előtérbe kerülése a hosszú távú értékteremtés ellenében hat. A reálgazdaságban a tőkebőség és az alacsony kamatok ellenére a beruházások visszaesése a gazdasági növekedésre is rányomta a bélyegét, ezért az alacsony kamatkörnyezethez alacsony növekedés párosult. A befektetői rövid távú érdekek a reálgazdaságban a tökeköltség csatornán keresztül érvényesülhettek. A saját tőke költsége és a beruházások között negatív kapcsolat mutatható ki, így a befektetői rövid távú érdekek előtérbe kerülése a döntéshozók által alkalmazott diszkontráták növelésén keresztül hat a beruházásokra, ami a beruházások elutasítását eredményezheti.

A tanulmány célja, hogy döntéshozói szemszögből mutassa be az alacsony kamatkörnyezet beruházási és befektetési döntésekre gyakorolt hatásának következményeit a döntéshozók intertemporális döntéseit vizsgálva. A tanulmány keretein belül elsősorban módszertani szempontból fogjuk megvizsgálni az befektetőktől racionálisan „elvárható” reakciókat, melyeket a jelenérték szabály motivál. Érdeklődésünk középpontjában a válságot követő évtized áll, amely egy elég hosszú időszaknak tekinthető az alacsony kamatkörnyezetben bekövetkező változások megfigyeléséhez és jól elkülöníthető annak ismeretében, hogy 2017 végén, az Egyesült Államokban megvalósult kamatemelést követően elkezdett a világ visszatérni a normál kerékvágásba.

A jelenérték szabály a jövőbeli pénzáramok diszkontált értékösszegén alapul, aminek adott bekerülési költség feletti részének maximálásában érdekelt a döntéshozó. A bekerülési költséget nem vesszük figyelembe, mivel az a döntések objektív, döntéshozó személyén kívül álló velejárója. Nincs okunk feltételezni, hogy a piac értékmérö funkciója a válság óta jelentős mértékben sérült volna, így a bekerülési költséget, vagy árat, árfolyamot külső tényezőként fogadjuk el. Csak a jelenlegi értékre koncentrálunk.

Ez azt jelenti, hogy egyelöre nem specifikáljuk az értékelendö pénzáramokat, azok lehetnek reálgazdasági projektek éppen úgy, mint kötvények, vagy részvények, esetleg egyéb alternatív befektetési lehetőségek. Bármi is legyen a befektetés tárgya, egyértelműen elfogadjuk, hogy a döntés a jövőbeli pénzáramok jelenértéke alapján hozható meg, az egyéb szempontokat figyelmen kívül hagyjuk.

A tanulmányban arra a kutatási kérdésre keressük a választ, hogy milyen döntési szabállyal ragadhatjuk meg a döntéshozók intertemporális preferenciáit az alacsony kamatkörnyezetben, ha a tradicionális jelenérték szabály összefüggései nem érvényesülnek. Annak érdekében, hogy ezt a kérdést megválaszolhassuk a döntések intertemporális jellegére fókuszálunk. Bemutatjuk a kamat és az érték közötti alapvető összefüggéseket, valamint a befektetői rövid távú szemléletet vizsgáló releváns szakirodalmat, majd numerikus példák segítségével szemléltetjük a befektetői rövid távú érdekek érvényesülésének következményeit.

\section{SZAKIRODALMI ÁTTEKINTÉS}

Az elmúlt évtizedben a monetáris politikai lazításoknak köszönhetően az alacsony kamatkörnyezet nemzetközileg és hazai viszonylatban is adottság. Ahogy az 1. ábrán is látható az 1 éves kamatlábak esetében, a válságot követően a monetáris politikai lazítások először az Amerikai Egyesült Államokban vezettek a kamatok csökkenéséhez, majd ezt követték az európai országok. Magyarország esetében ezektől eltérően a kamatcsökkentés két ciklusa figyelhető meg. Az 1. ábrán kiemeltük, hogy míg a vizsgált időszak elején Magyarország számottevő kamattöbblettel rendelkezett, addig válságot követő évtized végén a magyar 1 éves kamatláb az 
Egyesült Államokhoz képest alacsonyabb maradt. A megfigyelhetö kamatkülönbség történelmileg példátlan és nem független a hazai tőkepiacon zajló folyamatoktól. Ez a fordulat a monetáris politikai döntéshozókat is komoly dilemma elé állítja. A magyarországi monetáris politikában a válságot követően hangsúlyosan megjelenik a negatív kibocsátási rés bezárásának szándéka a kamatdöntésekben, így a gazdaság élénkítésére való törekvés tetten érhető (Abaligeti és tsai 2018).

A vizsgált időszak végén, az Amerikai Egyesült Államokban megvalósult kamatemelés által bekövetkezett monetáris politikai szigorítás a magyar törekvések ellenében gyakorol nyomást. A monetáris politikai intézkedéseket követően meghozott intertemporális döntések sok esetben nem a tradicionális jelenérték szabályon alapulnak. Az alacsony kamatkörnyezetben a tradicionális jelenérték szabályt alkalmazva a döntéshozók választása a hoszszú távú befektetésekre, beruházásokra esne, ennek ellenére a reálgazdaságban a beruházások visszaesése volt megfigyelhető a vizsgált időszakban, míg a tőkepiacokon az alacsony kamatok hatására hozamvadászat vette kezdetét. A befektetők a jelenérték növekvő változékonyságából adódó lehetőségeket próbálták meg kihasználni.

Nemzetközi összehasonlításban a reálgazdasági beruházások visszaesésére Blundell-Wignall \& Roulet (2015) több lehetséges magyarázattal is szolgálnak. A fejlett piacokon az értékteremtési rés szükülését, míg a fejlődő piacokon a globális értékláncok mentén történő optimalizálást és tőketranszferek, mint az osztalékfizetés és a részvényvisszavásárlások előtérbe kerülését jelölik meg lehetséges magyarázatként. Blundell-Wignall \& Roulet (2013) továbbá kihangsúlyozzák a saját tőke költség és az idegentőke költség közötti rés szerepét a beruházási döntésekben. A tanulmány bemutatja, hogy a saját tőke költség és a beruházások között negatív kapcsolat van, azaz ha egyre drágább a profit visszatartás, akkor csökkennek a beruházások. Továbbá amellett érvelnek, hogy a saját tőke költség és az idegen tőke költség közötti rés növekedése a tulajdonosi kifizetések irányába mozdítja a tőkeallokációt. Mankins et al. (2017) a beruházások visszaesését abban látják, hogy a döntéshozók által meghatározott diszkontráta nem tükrözi a tőkeköltséget. Lazonick (2014) is arra a következtetésre jut, hogy a vállalatok az alacsony tőkeköltség ellenére az osztalékfizetést és a részvényvisszavásárlásokat preferálják a profitvisszatartással és a beruházásokkal szemben.
Magyarországot tekintve a tökebőség ellenére a vállalatok nem használják ki a beruházási lehetőségeiket. A növekedési számviteli adatokat megvizsgálva is jól látható, hogy Magyarország tekintetében a 2006-2009 időszakot kivéve, a tőke már nem meghatározó tényezője az egy före jutó GDP növekedésének (Kónya 2015). Magyarország esetében beruházások visszaesését Reszegi - Juhász (2017) az állami szerepvállalás növekedésével magyarázzák, amely negatívan hat a vállalati jövedelmezöségre és a hozamelvárások emelkedésén keresztül okozza a beruházások visszaesését. Szerb (2017) megerősíti, hogy a centralizáció és a vállalati adminisztrációs terhek növekedése negatívan hat a vállalatok versenyképességére. A beruházások területi megoszlását tekintve ugyancsak megfigyelhetjük, hogy a magyar gazdaságban elszigetelten jellenek meg olyan területek, amelyeket erős tőkevonzó képesség jellemez (Tóth-Pajor - Farkas 2017).

A nemzetközi összehasonlításban bemutatott jelenségek Magyarországon is megfigyelhetők (1. ábra). A külföldi tulajdonú vállalatok a globális értékláncok mentén optimalizálnak, magasabb osztalékot fizetnek, mint a hazai tulajdonúak. A magyar gazdaság hajtóerejét a hazai tulajdonú, kisebb hozzáadott értéket termelő, kivitelre koncentráló vállalatok adják (Reszegi - Juhász 2017). Magyarország esetében sajátosság, hogy a válságot követően beruházásélénkítő, államilag támogatott hitelprogramok segítették visszafordítani a beruházásoknak a hitelkínálat szükülése miatt bekövetkező visszaesését. A Magyar Nemzeti Bank becslései szerint a 20132015-ös időszakban a Növekedési Hitelprogram 1,7 százalékponttal járult hozzá a GDP növekedéséhez (Bauer 2016). 
1. ábra: Az 1 éves lejáratra vonatkozó kamatlábak alakulása az Amerikai Egyesült Államok, Németország, és Magyarország állampapírpiacain

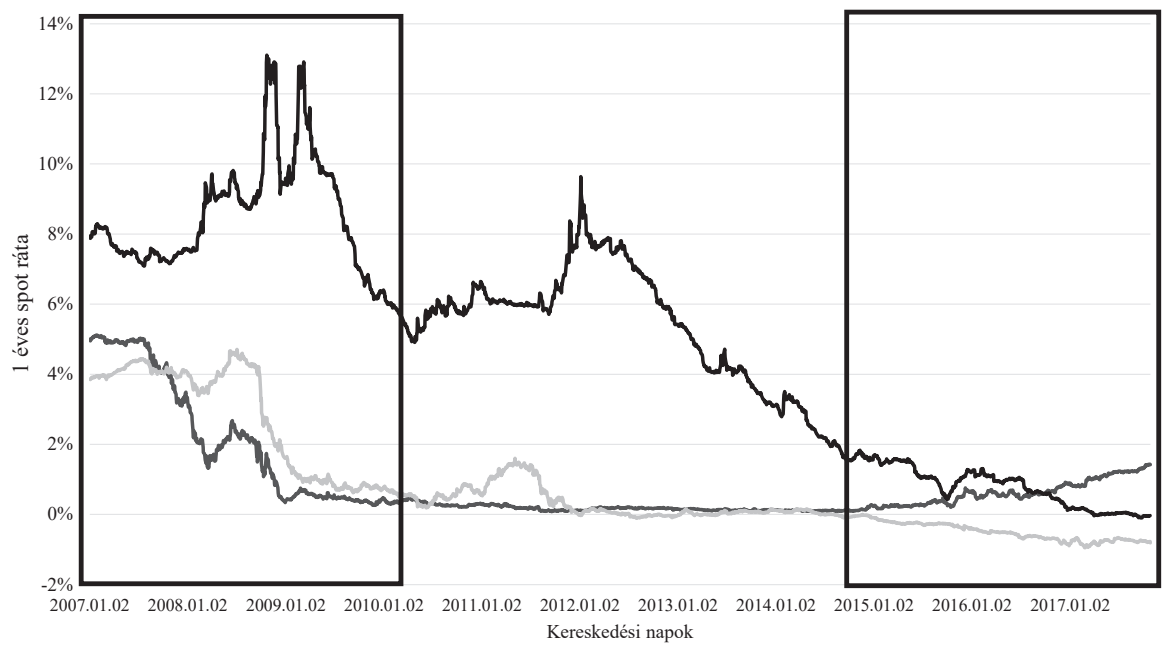

- USA $-\mathrm{DE}-\mathrm{HU}$

Forrás: Bundesbank, US Treasury, ÁKK Zrt.

A tőkepiacok esetében a monetáris politikai lazítások sosem látott mértékủ hozamvadászatot eredményeztek (Blundell-Wignall \& Roulet 2013). A tőkepiacokon egyre jobban elötérbe kerülnek a befektetői rövid távú érdekek, amelyek a hoszszú távú értékteremtés ellenében hatnak. Elsőként Miles (1993), majd Davies et al. (2014) találtak bizonyítékot a rövid távú befektetôi érdekek érvényesülésére tökepiacokon és érveltek amellett, hogy a rövid távú befektetői szemléletmód értéket rombol. Amennyiben a tőzsdei vállalatok a rövid távú befektetői érdekeket szolgálják ki a tőkepiacokon, úgy a negyedéves jelentésekre koncentrálnak és a tulajdonosi kifizetéseket részesítik elönyben, ezzel növelve a befektetésböl rövid távon realizálható hozamokat.

Továbbá a befektetők rövid távú szemlélete a tőkeköltség csatornán keresztül a beruházásokat is negatívan befolyásolja, akár a beruházások elutasítását eredményezheti. A rövid távú befektetői érdekek kiszolgálása miatt bekövetkező értékrombolás és a hosszú távú értékteremtés ellentéte miatt a vállalati döntéshozók célfüggvénye az arany középút megtalálása (Favaro 2014, Martin 2015, Mauboussin \& Rappaport 2016, Summers 2017). A befektetők rövid távú szemlélete egyfajta halasztási opcióként is értelmezhető, amit a technológiai fejlődés motivál. Az ipar 4.0, a mesterséges intelligencia, valamint az okos, összekapcsolt termékek megjelenése miatt újabb és újabb befektetési célpontok jelennek meg a tőkepiacokon, de a befektetők még kivárnak az új technológiák mellett történő hosszútávú elköteleződést illetően (Porter \& Heppelmann 2015).

A tökepiacokon megfigyelhető rövid távú befektetői szemléletmód bizonyításával szembe megy Giglio et al. (2014) megfigyelése, akik angol ingatlanpiaci lízingszerződéseket vizsgálva megmutatták, hogy a befektetők a beláthatatlanul távoli jövőben realizálható pénzáramokat a rövid távhoz hasonlóan nagyobb súllyal veszik figyelembe. A vállalati döntéseket tekintve Barton et al. (2017) összehasonlították a rövid távú befektetői érdekeket előtérbe helyező vállalatok és a hosszú távú értékteremtés felé elköteleződő vállalatok teljesítményét és megfigyelték, hogy azok a vállalatok, amelyek a hosszú távú értékteremtés mellett köteleződnek el jobban teljesítenek, mint a rövid távú befektetői érdekeket előtérbe helyező vállalatok. Az összehasonlítással alátámasztották a hosszú távú intertemporális preferenciák létjogosultságát. Bélyácz és Posza (2018) is amellett érvelnek, hogy a hosszú távú értékteremtésre alapozott befektetési stratégiáknak helye van a tőkepiacokon. 
Az előző példák is jól mutatják, hogy a döntéshozók intertemporális preferenciáit sok esetben nem ragadhatjuk meg a tradicionális jelenérték szabály keretei között. A befektetők intertemporális preferenciáinak vizsgálatára és az intertemporális döntések modellezésére a hiperbolikus diszkontálás módszerét alkalmazhatjuk. Phelps \& Pollack (1968) a generációk közötti intertemporális döntések modellezésére alkalmazták először ezt a módszert, ahol megmutatták, hogy a döntéshozók nagyobb súllyal veszik figyelembe a saját generációjuk jólétét, mint a jövőbeli generációk jólétét. Laibson (1997) amellett érvel, hogy a döntéshozók saját jövőbeli lehetőségeiket korlátozzák, ha nagyobb súllyal veszik figyelembe a rövidtávú kimeneteket. Rasmusen (2008) rámutat, hogy a hiperbolikus diszkontálás lényege a relatív időkezelés és levezeti a helyettesítés határrátáját a különböző függvényformák eseteiben. A tőkepiacokon a befektetők intertemporális preferenciáinak modellezésére Davies et al. (2014) és Miles (1993) is hasonló diszkontfüggvényeket használnak.

A pénzügyi viselkedéstan területén is születtek olyan eredmények, amelyek befektetői rövidtávú érdekek előtérbe kerülését vizsgálták. Thaler (1981) figyelte meg, hogy a döntéshozók intertemporális preferenciái sokszor a jelen irányába torzítanak, valamint időben inkonzisztensek. Thaler et al. (1997) megmutatták, hogy a befektetők rövid távú érdekeiket követik a befektetési döntések meghozatalakor, így közelmúltban elszenvedett veszteségek elkerülése érdekében, akár a hosszú távon elérhető haszonról is lemondanak. Ezt a jelenséget nevezzük rövidlátó veszteségkerülésnek. Kahnemann \& Lovallo (1993) a rövidlátó veszteségkerülést a szük keretezés problémájának tulajdonítják, mivel befektetők ebben az esetben nem veszik figyelembe a teljes képet, csak az egyedi befektetésekre koncentrálnak. A pénzügyi viselkedéstan előbb hivatkozott eredményei is abba az irányba mutatnak, hogy a hiperbolikus diszkontálás és a kvázi-hiperbolikus diszkontfüggvények jobban illeszkednek a döntéshozók intertemporális preferenciáihoz.

A szakirodalmi áttekintés alapján érdekes megfigyelés és a kutatási kérdésünk relevanciáját, valamint a tanulmány hiánypótló jellegét is alátámasztja, hogy sok esetben a döntéshozók intertemporális preferenciái sem a reálgazdasági beruházások sem a tőkepiaci befektetések esetében nem ragadhatók meg a tradicionális jelenértékszabály összefüggéseivel. A monetáris politikai intézkedések gazdaságélénkítési törekvései ellenére a csökkenő kamatokhoz nem társult növekvő beruházási kedv. A reálgazdaságban a vállalati jövedelmezőséget csökkentő tényezők, és a tőketranszferek előtérbe kerülése, míg a tőkepiacokon a rövid távú befektetői érdekek állnak szemben a hosszú távú befektetések, beruházások értéknövekményével. A döntéshozók az alacsony kamatkörnyezetben sok esetben nagyobb súllyal veszik figyelembe a rövid távon realizálható pénzáramokat a hosszú távon realizálható pénzáramokkal szemben, így az intertemporális döntéseik során a rövid távot részesítik előnyben a hosszú távval szemben.

\section{A RACIONÁLISAN „ELVÁR- HATÓ" REAKCIÓK ${ }^{2}$}

Az alacsony kamatkörnyezetben a döntéshozók racionálisan elvárható reakcióit a tőkeérték függvények segítségével szemléltethetjük, amelyekkel a döntéshozók által alkalmazott diszkontráta függvényében jeleníthetjük meg a jelenértéket. Adott lejáratra egységnyi hozamot biztosító, úgynevezett elemi értékpapírok tőkeérték függvényeit vizsgálva megfigyelhetjük, hogy a jelenérték a diszkontráta növekedése mellett csökken, illetve minél hosszabb a futamidő annál változékonyabbá válik a jelenérték.

Az elemi értékpapírok jelenértékének ismeretében bármilyen pénzáramlás jelenértéke felírható. Így a futamidő alatt változatlan diszkontrátát feltételezve a különböző lejáratú elemi értékpapírok sorozataként állítható elő a jelenérték meghatározásához szükséges (1) diszkontfüggvény.

,ahol

$$
D(T)=(1+r)^{-T}
$$

1. $D(T)$ a diszkontfüggvény értékét adott lejáratra,

2. r a diszkontrátát,

3. T a lejáratot jelöli.

Vizsgáljunk meg egy egyszerü példát, amelyben összeadjuk a diszkontfüggvény elemeit a 30 éves lejáratig. Ekkor egy olyan pénzáram sorozat jelenértékét határozzuk meg, amely minden periódusban egységnyi hozamot termel. Mivel ebben a példában a pénzáram sorozat tagjai megegyeznek, így egy járadékot (annuitást) kapunk. Ettől az absztrak-

2 A tankönyvekből is ismert gondolatmenet ismertetésével célunk a racionálisan „elvárható” reakciók megvilágítása, és szembeállítása a valós döntési helyzetekkel, amelyek vizsgálata adja a tanulmány újdonságtartalmát. 
ciótól eltekintve, a befektetési lehetőségek jelenértéke felírható a diszkontfüggvény segítségével, hiszen a valós befektetési lehetőségek pénzáramai az egységnyi hozam többszöröseként értelmezhetők. Ekkor a pénzáramok és a diszkontfüggvény elemeinek szorzatösszegeként határozhatjuk meg a jelenértéket. Például egy kamatszelvényes kötvény esetében a kamatszelvények nagysága és a névérték határozza meg a pénzáramok sorozatát. Az 1. táblázat az általunk vizsgált annuitás tőkeérték függvényének elemeit mutatja be.

\section{1. táblázat: A diszkontfüggvény elemeinek összege különböző diszkontráták mellett}

\begin{tabular}{|l|c|c|c|c|c|c|c|}
\hline Diszkontráta $(\mathrm{r})$ & $10 \%$ & $8 \%$ & $6 \%$ & $4 \%$ & $3 \%$ & $2 \%$ & $1 \%$ \\
\hline Jelenérték $\left(P V=\sum_{T=1}^{T=30} D(T)\right)$ & 9,43 & 11,26 & 13,76 & 17,29 & 19,60 & 22,40 & 25,81 \\
\hline
\end{tabular}

Forrás: saját szerkesztés

Ha a döntéshozók racionálisan ,elvárható” reakcióit vizsgáljuk, akkor abból indulhatunk ki, hogy a kamatok csökkenése a döntéshozó által alkalmazott diszkontrátát csökkenti. Beruházások esetében ez a tökeköltség csökkenésén keresztül jelenik meg, míg a tőkepiaci befektetések esetében a megkövetelt megtérülés csökken. A kamatcsökkenés hatásának vizsgálatához ismernünk kell a diszkontráta változásának pénzáramlásra gyakorolt hatását, amit az átlagidő segítségével mérhetünk (Roelse et al. 1938). Az átlagidő az egyedi pénzáramok jelenértékének súlya és az esedékességük szorzatösszegeként áll elö. A diszkontráta növekedése esetén az átlagidő csökken, míg a diszkontráta csökkenése esetében növekszik.

$\mathrm{Az}$ átlagidővel a diszkontráta párhuzamos eltolódásának hatását tudjuk megragadni (Ulbert 2002). A diszkontráta csökkenése esetén a magasabb átlagidő nagyobb nyereséget ígér, míg a diszkontráta növekedése esetén az alacsony átlagidő kisebb veszteséget eredményezhet.

A vizsgált annuitást tekintve a diszkontráta csökkenése esetén, a hosszútávon realizálható pénzáramok relatív szerepe felértékelődik a rövidtávon realizálható pénzáramokhoz képest, így a diszkontráta csökkenése a befektetési időhorizont kiszélesedésével jár. Ugyanerre következtetésre jut Ulbert és Takács (2018) az érték időkomponenseinek vizsgálata során, amikor megállapítják, hogy az alacsony diszkontráta esetében a vállalatértékelés kétfázisú modelljében a tervezési periódus relatív súlytalan a végtelenbe vetített hozamhoz képest

Ahogy a (2) egyenletben is látható, az átlagidő szoros összefüggésben van a jelenérték volatilitásával, amely a tőkeérték függvény diszkontráta szerinti parciális deriváltjaként határozható meg (Brealy - Myers 2005). A $\frac{D}{1+r}$ hányadost módosított átlagidőnek nevezzük. A diszkontráta csökkenés esetén az átlagidő növekszik, így a módosított átlagidő növekedése figyelhető meg, ami a jelenérték volatilitásának növekedését jelzi. Az alacsony kamatkörnyezetben a jelenérték volatilitása nagyobb, amely spekulációnak adhat teret. A változékony jelenérték a pénzügyi instrumentumok valós értékének meghatározását is megnehezíti, amely ugyancsak hatással van az árfolyamokra. A valós érték és az árfolyamok kapcsolatáról közöl új eredményeket Takács - Szücs (2018), valamint Szücs - Ulbert (2017), akik megállapítják, hogy a valós értékelés eredményhatása és az árfolyamok között szignifikáns kapcsolat van.

$$
\frac{\partial P V}{\partial r}=-P V \times \frac{D}{1+r}
$$

,ahol

1. PV a pénzáramok és a diszkontfüggvény elemeinek szorzatösszegeként meghatározott jelenértéket,

2. r a diszkontrátát,

3. D az átlagidőt jelöli.

A döntéshozók a diszkontráta változásának jelenértékre gyakorolt hatását egy Taylor-sor segítségével becsülhetik meg, amelyben a változást a tőkeérték függvény diszkontráta szerinti első és második parciális deriváltjával közelíthetjük. Az első derivált meghatározásához az átlagidőt kell ismernünk, míg a második derivált kiszámításához a konvexitást kell meghatározni.

$\mathrm{Az}$ átlagidő hatásának megértéséhez vizsgáljuk meg, hogy egy döntéshozó, hogyan választ két azonos árral és hozammal rendelkező kötvény közül. Az egyik kötvény esetében az átlagidő magasabb, így a döntést a diszkontráta változásának iránya határozza meg. A diszkontráta csökkenése 
esetében a magasabb átlagidővel rendelkező kötvény árának növekménye meghaladja az alacsonyabb átlagidővel rendelkező kötvény árának növekményét köszönhetően a tőkeérték függvény nagyobb meredekségének. A diszkontráta csökkenés esetében a döntéshozó számára a hoszszú távú befektetések ígérnek nagyobb jelenérték növekményt. Ellentétes irányú változás esetén a magasabb átlagidővel rendelkező kötvény árának csökkenése meghaladja az alacsonyabb átlagidővel rendelkező kötvény árának csökkenését, így ebben az esetben a mérleg az alacsonyabb átlagidővel rendelkezö kötvény felé billen.

A diszkontráta változás esetében a másik fontos tényező a cash flow súlyok szórásának változása. Ez a hatás a konvexitás segítségével mérhetö. A konvexitás az egyedi pénzáramok súlya és esedékességük négyzetének szorzatösszegeként számítható ki. Példánkat folytatva, ha a kötvények átlagideje megegyezik, akkor a két kötvény közötti választásban a konvexitás vizsgálata segíthet. Annak a kötvénynek a konvexitása nagyobb, amely esetében a pénzáramok időben változékonyabbak. A befektetési döntések során a nagyobb konvexitással rendelkező kötvény élvez előnyt, mert ebben az esetben a diszkontráta csökkenés hatására bekövetkező ár növekedés nagyobb mértékü, míg a diszkontráta növekedés esetében a nagyobb konvexitás kisebb árcsökkenést eredményez. A konvexitás segítségével, egy sokkal átfogóbb képet kaphatunk a jelenlegi érték diszkontráta szerinti változásáról. Ekkor a diszkontráta változás jelenértékre gyakorolt hatása a (3) egyenlettel becsülhető.
$\Delta P V \approx-P V \times \frac{D}{1+r} \times \Delta r+\frac{1}{2} \times P V \times C \times \Delta r^{2}$

,ahol

1. $\triangle P V$ a jelenérték változását

2. $\quad P V$ a jelenértéket

3. $D$ az átlagidőt

4. C a konvexitást

5. $r$ a diszkontrátát

6. $\Delta r$ a diszkontráta változását jelöli.

A vizsgált 30 éves annuitás esetében a $2 \%$-os, valamint $1 \%$-os diszkontráta változás jelenlegi értékre gyakorolt hatásának becsült értékeit a 2 . táblázat szemlélteti. A 2. táblázatban mindig az adott diszkontrátához tartozó jelenértékből indultunk ki és becsültük meg a jelenérték változását a diszkontráta $2 \%$-os, valamint $1 \%$-os csökkenése esetén. Jól látható, hogy a diszkontráta csökkenése mellett az átlagidő és a konvexitás növekszik, aminek következményeként a jelenérték volatilitása növekszik. Alacsonyabb diszkontráta esetén a diszkontráta további csökkenése egyre nagyobb értékváltozást okoz. Az egységnyi diszkontráta változásra jutó jelenértékváltozás a diszkontráta csökkenése esetén növekszik. Alacsonyabb diszkontrátából kiindulva, az azonos nagyságú diszkontráta csökkenés, növekvő eltéréseket eredményez a becsült és a tényleges jelenérték változás között.

\section{2. táblázat: A diszkontráta változás jelenértékre gyakorolt hatása}

\begin{tabular}{|l|r|r|r|r|r|r|r|}
\hline Diszkontráta & $10 \%$ & $8 \%$ & $6 \%$ & $4 \%$ & $3 \%$ & $2 \%$ & $1 \%$ \\
\hline Átlagidő & 9,176 & 10,190 & 11,342 & 12,627 & 13,314 & 14,025 & 14,756 \\
\hline Konvexitás & 136,164 & 162,314 & 193,358 & 229,449 & 249,322 & 270,315 & 292,313 \\
\hline Konvexitás hatás & 0,257 & 0,365 & 0,532 & 0,198 & 0,244 & 0,302 \\
\hline Átlagidó hatás & 1,573 & 2,124 & 2,946 & 2,100 & 2,534 & 3,080 \\
\hline Becsült jelenérték változás & 1,830 & 2,490 & 3,478 & 2,298 & 2,778 & 3,382 \\
\hline Tényleges jelenértékváltozás & 1,831 & 2,507 & 3,527 & 2,308 & 2,796 & 3,411 \\
\hline Eltérés & 0,001 & 0,017 & 0,049 & 0,010 & 0,018 & 0,029 \\
\hline
\end{tabular}

Forrás: saját szerkesztés 
A bemutatott példa alapján levonhatjuk a következtetést, hogy a diszkontráta csökkenés hatására a hosszabb távon realizálható pénzáramok súlya felértékelődik, a jelenérték volatilitása megnövekszik és a nagyobb átlagidő nagyobb hozamokat ígér. A diszkontráta csökkenés esetében a döntéshozó számára a hosszú távú befektetések, beruházások jelenértéke nagyobb mértékben növekszik a rövid távú befektetések, beruházások értékével szemben, így az intertemporális döntések esetében a diszkontráta csökkenés a hosszú táv felé történő elmozdulásra ösztönzi a döntéshozókat.

\section{A RÖVIDTÁVÚ ÉRDEKEK ELŐTÉRBE HELYEZÉSE}

Ahogy a szakirodalom kutatásunk is alátámasztja, a monetáris politikai intézkedéseket követően meghozott intertemporális döntések esetében sokszor nem a racionálisan „elvárható” reakció köszön vissza. A tőkepiacon ennek egyik oka a befektetők rövid távú érdekeinek előtérbe kerülése, amely a tőkeköltség csatornán keresztül a vállalati beruházási döntéseket is befolyásolja. A döntéshozók nagyobb súllyal veszik figyelembe a rövid távon realizálható pénzáramokat szemben a hosszú távon realizálható pénzáramokkal.

Ezekben az esetekben az intertemporális döntéseket a tradicionális jelenérték szabály helyett a hiperbolikus diszkontálás szabályait alkalmazva ragadhatjuk meg. A döntéshozók intertemporális preferenciáit Davies et al. (2014) munkáját követve kvázi-hiperbolikus diszkontfüggvényekkel modellezhetjük. Az intertemporális preferenciák a diszkontfüggvényben diszkonttöbbletként jelennek meg, amit a (4) egyenletben a $\beta$ paraméter jelöl. Ha $\beta<1$, akkor a döntéshozóra rövid távú szemlélet jellemző, mivel nagyobb súllyal veszi figyelembe a rövid távon realizálható pénzáramokat. Ha $\beta>1$, akkor a döntéshozóra hosszú távú szemléletmód jellemző, mert a hosszú távon realizálható pénzáramokat veszi nagyobb súllyal figyelembe.

$$
\left.D_{I}(T)=\beta^{T} \times[1+r)\right]^{-T}
$$

,ahol

1. $D_{I}(T)$ a döntéshozó intertemporális preferenciáit leíró diszkontfüggvényt,

2. $r$ a diszkontrátát,

3. T a lejáratot,

4. $\quad \beta$ az intertemporális preferenciákat leíró diszkonttöbbletet jelöli.
A döntéshozók rövid távú intertemporális preferenciáinak megértéséhez nézzünk meg egy egyszerü példát. Ebben a példában a döntéshozó egy beruházásról dönt, amely kezdeti költsége 1000 eFt. A beruházás a következő 10 évben évente 200 eFt pénzáramot termel. Ekkor a beruházás nettó jelenértékét $10 \%$ diszkontrátát feltételezve az (5) egyenlet alapján számolhatjuk ki, amire 229 eFt-ot kapunk. A döntéshozó racionálisan elvárható reakciója a beruházás elfogadása és megvalósítása lesz.

$N P V=-1000 e F t+\frac{200 e F t}{1,1^{1}}+\frac{200 e F t}{1,1^{2}}+\frac{200 e F t}{1,1^{3}}+\ldots+\frac{200 e F t}{1,1^{10}}=229 e F t$

Nézzük meg az esetet, amikor a döntéshozó a rövid távú érdekeit helyezi élőtérbe. Ekkor egy pótlólagos diszkonttöbblet jelenik meg, amely a döntéshozó intertemporális preferenciáit szemlélteti. Egy valós döntés során ez a diszkonttöbblet, akkor értelmezhető, ha a tőkeköltségtől eltérő diszkontrátát, úgynevezett küszöbértéket alkalmazunk a beruházás gazdaságosság értékelése során, amely az egyéni preferenciáinkat tükrözi a hosszú távú elköteleződés tekintetében.

Tegyük fel, hogy a $\beta=0,95$. Ekkor a nettó jelenértéket a (6) egyenlet alapján számolhatjuk ki, amire -26 eFt-ot kapunk. Ebben az esetben a döntéshozó elutasítja a beruházást, az nem kerül megvalósításra. Doobs (2009) szerint, reálopciós keretrendszerben vizsgálódva nem feltétlenül a beruházás elutasítása a cél sokkal inkább a hoszszú távú elköteleződés halasztása. Ekkor egy beruházásidőzítési problémával állunk szemben, amelyben a beruházás akkor kerül megvalósításra, ha teljesíti a döntéshozó által meghatározott küszöbértékeket. A példában megtérülési idő szabályt alkalmazva is ugyanerre a következtetésre juthatunk.

$$
\begin{aligned}
& N P V=-1000 e F t+\frac{200 e F t \times 0,95^{1}}{1,1^{1}}+\frac{200 e F t \times 0,95^{2}}{1,1^{2}}+ \\
& \frac{200 e F t \times 0,95^{3}}{1,1^{3}}+\ldots+\frac{200 e F t \times 0,95^{10}}{1,1^{10}}=-26 e F t
\end{aligned}
$$

Ahogy a példánk is jól szemlélteti a döntéshozók rövid távú érdekeinek előtérbe helyezése értéket rombol, a tőkeköltség csatornán keresztül hat a beruházásokra és a tradicionális jelenérték szabálytól alacsonyabb nettó jelenértéket eredményez.

Davies et al. (2014) empirikus vizsgálatokkal is bizonyítják a rövid távú érdekek érvényesülését az intertemporális tőkeallokációs döntések vonatkozásában. Az 1995-től 2004-ig terjedő időszakban Anglia és az Egyesült Államok tökepiacait vizsgálva átlagosan $\beta=0,938$ értékét becsülnek az intertemporális preferenciák miatt megjelenő 
diszkonttöbbletként. Továbbá levezetik, hogy a befektetői rövid távú szemléletmód a beruházások helyett a tulajdonosi kifizetések irányába mozdítja a vállalati tőkeallokációt. Ezek a vizsgálatok megmutatták, hogy a tökepiacokon a döntéshozók a tradicionális jelenérték szabállyal ellenében a rövidtávú érdekeiket helyezik előtérbe az intertemporális tőkeallokációs döntéseik során, ami a tőkeköltség csatornán keresztül a vállalati beruházásokra is hatással van.

\section{A HELYETTESÍTÉS HATÁRRÁTÁJA}

A döntéshozók intertemporális preferenciáinak vizsgálatakor arra keressük a választ, hogy a döntéshozók számára mekkora a helyettesítési arány a jelen és a különböző jövőbeli lejáratok között. Ennek számszerüsítésére a diszkontfüggvények esetében a helyettesítés határrátáját alkalmazhatjuk. A helyettesítés határrátája megmutatja, hogy az egységnyi jelenbeli tőkéről történő lemondás mekkora jövőbeli hozamígéret ellenében valósulhat meg. A helyettesítés határrátája a diszkontfüggvény reciprokaként értelmezhető (Rasmusen 2008). Az (1) egyenletben definiált diszkontfüggvény esetében a helyettesítés határrátája a (7) egyenlet alapján definiálható, míg a (4) egyenletben vizsgált diszkontfüggvény esetén a helyettesítés határrátája a (8) egyenlet alapján határozható meg.

$$
\begin{aligned}
H H R_{T} & =\left(\frac{1}{q}\right)^{-T} \\
H H R_{I} & =\left(\frac{\beta}{q}\right)^{-T}
\end{aligned}
$$

,ahol

1. $H H R_{T}$ a helyettesítés határrátáját a tradicionális jelenérték szabály esetén,

2. $H H R_{I}$ a helyettesítés határrátáját az intertemporális preferenciák vizsgálata esetén,

3. $q=1+r$,

4. $\mathrm{r}$ a diszkontrátát,

5. $T$ a lejáratot,

6. $\beta$ az intertemporális preferenciákat leíró diszkonttöbbletet jelöli.
A tradicionális jelenérték szabályt leíró diszkontfüggvény esetében a helyettesítés határrátáját a (7) egyenlet alapján kiszámolva megfigyelhetjük, hogy a hosszabb lejáratokra vonatkozóan a helyettesítés határrátája nagyobb, de a diszkontráta csökkenése során ez a különbség egyre inkább eltűnik. Az alacsony kamatkörnyezet kiegyenlíti a helyettesítés határrátáját a hosszú és a rövid táv között. Tetten érhető a hosszú táv felértékelödése a rövid távval szemben. Ebben az esetben a döntéshozók a diszkontráta csökkenése esetén egyre kevesebb kompenzációt várnak azért, hogy a jelenben rendelkezésre álló tőkéjüket hosszú távú hozamígéretekre cseréljék.

A 2. ábrán a helyettesítés határráták különbözete látható a különböző lejáratokra a (8)-(7) különbséget szemléltetve. A tradicionális jelenértékszabályt leíró diszkontfüggvényhez viszonyítva egy rövid távú érdekeit előtérbe helyező döntéshozót () vizsgálva megállapíthatjuk, hogy míg a rövid lejáratok esetében csak kis mértékben haladja meg a helyettesítés határrátája a (7) egyenlet alapján számolt rátát, addig a hosszú táv esetében a helyettesítési arány nagyságrendekkel nagyobb. Ez arra utal, hogy a döntéshozók a diszkontráta csökkenés ellenére nagyobb mértékü kompenzációt várnak azért, hogy a jelenben rendelkezésre álló tőkéjüket hosszú távú hozamígéretekre cseréljék. 


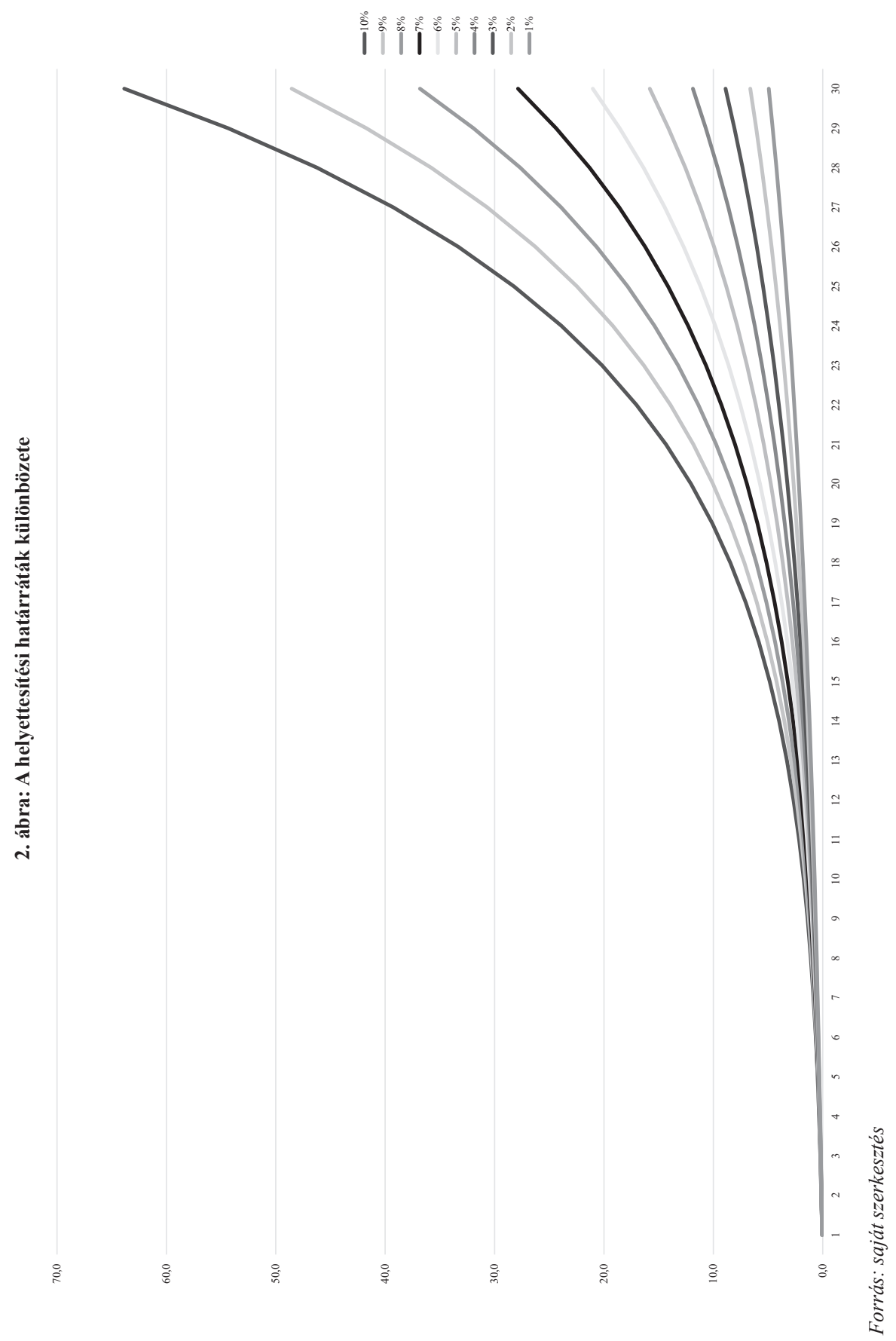


A helyettesítés határrátájának vizsgálatából is kiderül, hogy a döntéshozók mindkét esetben elötérbe helyezik a jelenben rendelkezésre álló tőkét egy jövőbeli hozamígérettel szemben. A tradicionális jelenérték szabály esetében a diszkontráta csökkenésével a helyettesítés határrátája kiegyenlítődik a hosszú és a rövidtáv között, míg a rövid távú érdekeiket elötérbe helyező döntéshozók sokkal nagyobb kompenzációt várnak azért, hogy a tökéjüket hosszú távú lehetőségekbe fektessék.

\section{KÖVETKEZTETÉSEK}

Tanulmányunkban arra a kutatási kérdésre kerestük a választ, hogy milyen döntési szabállyal ragadhatjuk meg a döntéshozók intertemporális preferenciáit az alacsony kamatkörnyezetben, ha a tradicionális jelenérték szabály összefüggései nem érvényesülnek. A kutatási kérdés megválaszolása során szembeállítottuk a tradicionális jelenérték szabályt alkalmazó döntéshozók és a rövid távú érdekeket elötérbe helyező döntéshozók intertemporális választásait.

A tradicionális jelenérték szabályt alkalmazva egy tankkönyvekből már ismert gondolatmenet segítségével bemutattuk, hogy a diszkontráta csökkenése a hosszú távú pénzáramok felértékelődésével kiszélesíti a befektetési időhorizontot. Így a diszkontráta csökkenése esetében a hosszú távú befektetések és beruházások értéknövekménye meghaladja a rövid távú lehetőségek értéknövekményét, ami a befektetőket a hosszú táv irányába történő elmozdulásra ösztönzi. Ezen felül az alacsony kamatkörnyezetben a jelenérték növekvő volatilitása spekulációnak, hozamvadászatnak ad teret.

A tanulmány legfontosabb eredménye annak bemutatása, hogy azokban az esetekben, amikor az intertemporális döntések vonatkozásában nem érvényesül a tradicionális jelenérték szabály, a döntések modellezésére kvázi-hiperbolikus diszkontfüggvényeket alkalmazhatunk, amelyek magyarázatul szolgálhatnak a beruházások visszaesésére, valamint a tőketranszferek előtérbe kerülésére. Az empirikus vizsgálatok a tőkepiacok esetében már megmutatták, hogy a befektetők intertemporális döntéseit tekintve a tőkepiacokon a rövid távú érdekek érvényesülnek, amelyek a tőkeköltség csatornán keresztül a vállalati beruházásokra is hatással vannak. A rövid távú érdekeket elötérbe helyező döntéshozók esetében az intertemporális preferenciákat leíró diszkonttöbblet a tradicionális jelenérték szabály által meghatározott értéknél alacsonyabb értéket eredményez, ami értékes befektetési és beruházási lehetőség elutasításához vezethet, ezzel értéket rombol. Ugyanezt az eredményt hangsúlyozva a helyettesítés határrátájának vizsgálatával megállapítottuk, hogy a diszkontráta csökkenése esetén a rövid távú érdekeket előtérbe helyező döntéshozók nagyobb kompenzációt várnak azért, hogy lemondjanak a jelenben rendelkezésre álló tőkéjükről egy hosszú távon realizálható hozamért cserébe.

A kutatási kérdésünkre válaszként levonhatjuk a következtetést, hogy a hiperbolikus diszkontálás és a kvázi-hiperbolikus diszkontfüggvények alkalmazása az intertemporális tőkeallokációs döntések alternatív döntési keretrendszereként jelennek meg a tradicionális jelenérték szabállyal szemben a monetáris intézkedések hatására kialakult alacsony kamatkörnyezetben. 


\section{HIVATKOZÁSOK}

Abaligeti G. - Németh K. - Schepp, Z. (2018), „Időben változó Taylor-szabály a hazai monetáris politika jellemzésére", Közgazdasági Szemle, 65 1, 24-43 ISSN 0023-4346 DOI: https:// doi.org/10.18414/ksz.2018.1.24

Barton, D. (2017), "Finally, Proof That Managing for the Long Term Pays Off," Harvard Business Review, 2017 February

Bauer P. (2016), „Növekedési Hitelprogram - a Magyar Nemzeti Bank hitelösztönző eszközének tapasztalatai”, MNB tanulmánykötet https://www.mnb.hu/letoltes/novekedesi-hitelprogram-a-magyar-nemzeti-bank-hitelosztonzo-eszkozenek-tapasztalatai.pdf

Bélyácz I. - Posza A. (2018), „Valóban kiment-e a divatból a fundamentális analízis?" Gazdaság és Pénzügy, 5 3, 198-235

Blundell-Wignall, A. and Roulet, C. (2013), 'Longterm investment, the cost of capital and the dividend and buyback puzzle", OECD Journal: Financial Market Trends, 139-52. DOI: https:// doi.org/10.1787/fmt-2013-5k41z8t0518s

Blundell-Wignall, A. and Roulet, C. (2015), 'Infrastructure versus other investments in the global economy and stagnation hypotheses", OECD Journal: Financial Market Trends, 2 7-45 DOI: https://doi.org/10.1787/fmt-2014-5js4sbd025d6

Brealey, R. A. - Myers, S. C. (2005), Modern vállalati pénzügyek, Panem Könyvkiadó, Budapest

Davies, R., Haldane, A. G., Nielsen, M., Pezzini, S. (2014), "Measuring the costs of short-termism", Journal of Financial Stability, 12 16-25 DOI: https://doi.org/10.1016/j.jfs.2013.07.002

Dobbs, I. M. (2009), "How bad can short termism be?-A study of the consequences of high hurdle discount rates and low payback thresholds", Management Accounting Research, 20 2, 117-28 DOI: https://doi.org/10.1016/j. mar.2008.10.007

Favaro, K. (2014), "Long-Termism Is Just as Bad as Short-Termism", Harvard Business Review, 2014 September

Giglio, S., Maggiori, M. and Stroebel, J. (2014), "Very Long-Run Discount Rates", The Quarterly Journal of Economics, 130 1, 1-53 DOI: https://doi.org/10.3386/w20133

Kónya I. (2015), „Több gép vagy nagyobb hatékonyság? : Növekedés, tőkeállomány és termelékenység Magyarországon 1995-2013 között", Közgazdasági Szemle, 62 11, 1117-39 DOI: https://doi.org/10.18414/ksz.2015.11.1117
Kahneman, D., and Lovallo, D. (1993), "Timid choices and bold forecasts: A cognitive perspective on risk taking", Management Science, 39, 17-31. DOI: https://doi.org/10.1287/ mnsc.39.1.17

Laibson, D. (1997), "Golden Eggs and Hyperbolic Discounting", The Quarterly Journal of Economics, 112 2, 443-78 DOI: https://doi. org/10.1162/003355397555253

Lazonick, W. (2014), "Profits without prosperity", Harvard Business Review 2014 September

Mankins, M., Harris, K. and Harding, D. (2017), "Strategy in the Age of Superabundant Capital", Harvard Business Review March-April 2017

Martin, R. L. (2015), "Yes, Short-Termism Really Is a Problem", Harvard Business Review 2015 October

Mauboussin, M. J. and Rappaport, A. (2016), "Reclaiming the Idea of Shareholder Value", Harvard Business Review 2016 July

Miles, D. (1993), "Testing for Short Termism in the UK Stock Market", The Economic Journal, 103 421, 1379-96 DOI: https://doi. org $/ 10.2307 / 2234472$

Phelps, E. S. and Pollak, R. A. (1968), „On Second-Best National Saving and Game-Equilibrium Growth", The Review of Economic Studies, 35 2, 185-99. DOI: https://doi. org/10.2307/2296547

Porter, M. and Heppelmann, J. (2015), ”How smart connected products are transforming companies", Harvard Business Review, October 2015, 96-114

Rasmusen, E. B. (2008), "Some Common Confusions About Hyperbolic Discounting", SSRN Electronic Journal. DOI: https://doi. org/10.2139/ssrn.1091392

Reszegi L. - Juhász P. (2017), „Gátak a magyar vállalati növekedésben”, Vezetéstudomány / Budapest Management Review XLVIII. 6-7, DOI: https://doi.org/10.14267/veztud.2017.06.04

Roelse, H. V., Macaulay, F. R. and Mitchell, W. C. (1938), „Some Theoretical Problems Suggested by the Movements of Interest Rates, Bond Yields and Stock Prices in the United States Since 1856", Journal of the American Statistical Association, 33 203, 609. DOI: https://doi. org $/ 10.2307 / 2279712$

Summers, L. H. (2017), Is Corporate Short-Termism Really a Problem? The Jury's Still Out, Harvard Business Review 2017 February

Szerb, L. (2017), A vállalkozói ökoszisztéma Magyarországon a 2010-es években - helyzetértékelés és szakpolitikai javaslatok, Vezetéstudomány / Budapest Manage- 
ment Review, 48 6-7, 2-14 DOI: https://doi. org/10.14267/VEZTUD.2017.06.01

Szücs T. - Ulbert J. (2017), „A valós értékelés szerepe és mérése a hazai hitelintézeti szektorban," Hitelintézeti Szemle, 16 3, 51-74 DOI: https:// doi.org/10.25201/hsz.16.3.5173

Takács A. - Szücs T. (2018), „A valós értékelés tőkepiaci értékítéletre gyakorolt hatása európai nagybankok részvényeinél", Szigma, XLIX 3-4, 101-17

Thaler, R. H. (1981), "Some Empirical Evidence on Dynamic Inconsistency", Economics Letters, 8 3, 201-7 DOI: https://doi.org/10.1016/01651765(81)90067-7

Thaler, R. H., Tversky, A., Kahneman, D. and Schwartz, A. (1997), "The effect of myopia and loss aversion on risk taking: An experimental test", The Quarterly Journal of Economics, 112 2, 647-61 DOI: https://doi. org $/ 10.1162 / 003355397555226$

Tóth-Pajor Á. - Farkas R. (2017), „A vállalkozói ökoszisztémák térbeli megjelenésének modellezési lehetőségei - tények és problémák", Közgazdasági Szemle, 64 2, 123-39 DOI: http:// dx.doi.org/10.18414/KSZ.2017.2.123

Ulbert J. - Takács A. (2018), „Az értékteremtési folyamat időkomponensekre bontásának pénzügy-matematikai aspektusai”, Marketing és Menedzsment 52 1, 66-80

Ulbert J. (2002), Értékpapír értékelés, Pécsi Tudományegyetem Közgazdaságtudományi Kar 
Dr. habil. Schepp Zoltán PhD, egyetemi tanár, dékán schepp@ktk.pte.hu

Dr. habil Ulbert József CSc, intézetigazgató egyetemi docens ulbert@ktk.pte.hu

Tóth-Pajor Ákos, tanársegéd toth-pajor.akos@ktk.pte.hu

Pécsi Tudományegyetem Közgazdaságtudományi Kar

\section{Intertemporal Capital Allocation Decisions in the Low Interest Rate Environment}

\section{THE AIMS OF THE PAPER}

In this study, we investigate the impact of the low interest rate environment on the investment decisions. By formulating our research question, we wanted to know what kind of decision rule could describe the intertemporal preferences of decision makers in the low interest rate environment, if the traditional present value rule cannot explain the outcome of the decisions.

\section{METHODOLOGY}

To answer this research question we made a literature review and used numeric examples to introduce the rationally expected reaction of the decision makers. We also compared the intertemporal choices of decision makers who apply the traditional present value rule with those who have shortterm preferences. During the research, we investigated the reactions of the decision makers mainly from a methodological point of view and we concentrated on the intertemporal preferences using the assumption that the reactions of the decision makers are motivated by the present value rule. We investigated the last decade after the crisis, because it is a distinct period, which enabled us to introduce the changes induced by the low interest rate environment.

\section{MOST IMPORTANT RESULTS}

By applying the traditional present value rule, we showed that the decrease of the discount rate stretches the time horizon of the investments and the increasing volatility of the present value provide space for speculation and for chase of returns. As the most important result of our research, we argue that in the cases when the traditional present value rule cannot explain the intertemporal preferences of decision makers we can apply quasi-hyperbolic discount functions, which can explain the decrease of investments and the increase of capital transfers. In the case of decision makers with short-term preferences the excess discounting leads to lower present values compared to the traditional present value rule, thus these decision makers can forgo valuable investment.

\section{RECOMMENDATIONS}

To answer our research question, we can draw the conclusion, that hyperbolic discounting and quasi-hyperbolic discount functions emerge as an alternative decision making framework of the intertemporal capital allocation decisions in contrast of the traditional present value rule in the low interest rate environment.

Keywords: intertemporal allocation, intertemporal preferences, low interest rate environment, hyperbolic discounting, investor short-termism 